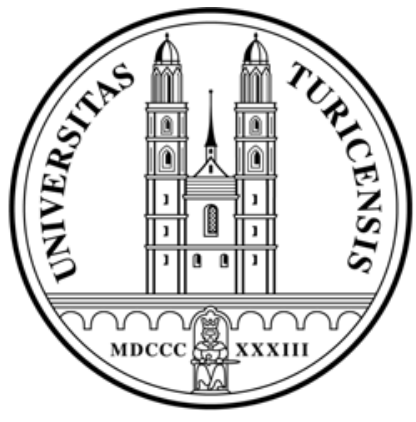

Institute for Empirical Research in Economics

University of Zurich

Working Paper Series

ISSN 1424-0459

Published in: Journal of Institutional and Theoretical Economics, Vol. 160, Nr. 3, 2004, 377-401

Working Paper No. 129

Introducing Procedural Utility:

Not only What, but also How Matters

Bruno S. Frey, Matthias Benz and Alois Stutzer

November 2002 


\title{
Introducing Procedural Utility: Not only What, but also How Matters
}

\author{
by \\ Bruno S. Frey, Matthias Benz and Alois Stutzer* \\ (University of Zurich and University of California at Berkeley)
}

October 2, 2002

\begin{abstract}
People not only care about outcomes, they also value the procedures which lead to the outcomes. Procedural utility is a potentially important source of human well-being. This paper aims at introducing the concept of procedural utility into economics, and argues that it should be incorporated more widely into economic theory and empirical research. Three building blocks of a concept of procedural utility are outlined and it is suggested how procedural utility can be fruitfully integrated. Evidence from a broad range of social sciences is reviewed in order to show that procedural utility is a relevant concept for economics. (98 words)
\end{abstract}

Keywords: procedural utility, outcome utility, institutions.

JEL-Codes: A00, A12, D60, D70

\footnotetext{
* Address for correspondence: Institute for Empirical Research in Economics, University of Zurich, Bluemlisalpstrasse 10, 8006 Zurich, Switzerland. Phone: +41-1-634 37 32/31; Fax: +41-1-634 49 07; E-mail: bsfrey@iew.unizh.ch, matbenz@iew.unizh.ch, astutzer@iew.unizh.ch. We are grateful to [will be inserted later] for helpful comments. The third author acknowledges financial support from the Swiss National Science Foundation.
} 


\section{Introduction}

Why are people, e.g. faculty members, often unhappy with a decision when they have not been properly consulted in the decision making process, even if they perfectly agree with the decision that has been reached? Why are individuals involved in lawsuits often more willing to accept a given judgment when they feel that court procedures were fair? And how can it be explained that workers are often not only concerned with organizational outcomes, but also with the ways these outcomes are determined?

This paper suggests that a common answer to these questions is procedural utility. Procedural utility means that people value not only actual outcomes, i.e. the 'what', but also the conditions and processes which lead to these outcomes, i.e. the 'how'. Procedural utility thus represents a completely different approach to human well-being than the standard approach applied in economics. The economic concept of utility is outcome-oriented: individual utility is seen as a result of benefits and costs associated with instrumental outcomes. In contrast, procedural utility refers to the non-instrumental pleasures and displeasures of processes.

People have preferences, for instance, about how they are treated in the market place, in the public realm, or within hierarchies. The decision making procedures, or institutions, applied in these contexts may importantly affect people's well-being. Institutions express judgements about the people involved that may greatly influence their self-worth. For example, it can be deeply disturbing to a person's sense of self if basic civil liberties are denied to him or her. Institutions also provide incentives to managers, politicians, tax authorities, judges and employers on how to treat fellow consumers, citizens, taxpayers, litigants or employees in everyday interactions, thereby generating utility over and above instrumental outcomes.

The goal of this paper is to introduce procedural utility into economics. We argue that procedural utility is an important determinant of human well-being that has to be incorporated more widely into economic theory and empirical research. So far, this has been largely neglected. However, in other social sciences, concepts similar to procedural utility have a long history. The present paper outlines three building blocks of a concept of procedural utility and offers thoughts on how procedural utility can be fruitfully integrated into the existing economic approach. Moreover, it reviews some of the evidence from a broad range of social sciences and areas in order to show that procedural utility is a relevant concept for economics. Finally, it is argued that procedural utility is of great policy relevance. 
The remainder of the paper is structured as follows: Section II outlines the concept of procedural utility and shows its broad psychological basis. Section III deals with the main sources of procedural utility. It first discusses institutionalized processes as an important source of procedural utility. Further, it looks at specific areas where procedural utility can be demonstrated to matter. In the economy, individuals have been shown to enjoy procedural utility in their capacity as consumers or income earners; in the polity and society as citizens subjected to different political and societal procedures; in organizations as employees confronted with different organizational procedures; and in law as litigants. Section IV explores various theoretical relationships between procedural utility and standard outcome utility. Three questions are addressed: To what extent can procedures and consequences be analyzed independently of each other, and to what extent should they be considered together? Is there a trade-off between procedural concerns and outcome concerns, or are they rather complements? Does the importance of procedural utility depend on the context of action, e.g. the available choice alternatives? Section V discusses policy consequences and concludes.

\section{A Concept of Procedural Utility}

Economic analysis has focused on tangible outcomes ever since the positivistic movement in economics in the 1930's. Without doubt, this was paramount for the success of the economic approach to behavior in the social sciences. Obviously, individuals care a lot about outcomes; economics has derived a powerful model of human behavior based on this insight (Becker 1976, Frey 1999, Lazear 2000). The success of the economic approach is based on a simple notion of utility. It employs an 'objectivist' position, based on observable choices made by individuals. Individual utility only depends on tangible goods and services and leisure. It is inferred from behavior (or revealed preferences), and is in turn used to explain the choices made. The notion that outcomes are not the only source of utility and not the only driving force behind behavior was thereby almost completely lost in economic analysis. ${ }^{1}$

Procedural utility, in contrast, means that there is something beyond instrumental outputs as they are captured in a traditional economic utility function. People may have preferences about how outcomes are generated. These preferences about procedures generate procedural utility.

\footnotetext{
${ }^{1}$ An exception may be the utility gained from gambling, which was already considered by Pascal (1670), and later by Marschak (1950) and by von Neumann and Morgenstern (1953) to be incompatible with expected utility maximization (see also Harsanyi 1993). Recently, Le Menestrel (2001) established axioms for a model of rational behavior combining processes and consequences in gambling. However, gambling may also qualify as non-tangible consumption, which is readily accessible with the standard approach in economics. The most prominent economist who has repeatedly argued that economic choice models should combine preferences for outcome with those for processes is Sen $(1995,1997)$.
} 
We propose a concept of procedural utility that goes beyond outcomes and that contributes to a broader understanding of humans' non-instrumental concerns. The concept of procedural utility deviates in three important aspects from the traditional utility concept in economics:

(i) Procedural utility emphasizes the hedonic content of utility. Utility is understood as wellbeing, pleasure and pain, positive and negative affect or life satisfaction. ${ }^{2}$ Based on the rediscovery of hedonic well-being, there is now a substantial amount of research on reported subjective well-being or happiness in economics (see Frey and Stutzer 2002a and Oswald 1997 for reviews). ${ }^{3}$

(ii) Procedural utility starts from the notion that people have a sense of self. They care about how they perceive themselves as human beings and how they are perceived by others. They thus have a reflexive consciousness. ${ }^{4}$ A person's evaluation of the self is reflected in her selfesteem and thus in an affective response contributing to the general well-being. Feedback information to the self is provided as a byproduct of decision-making and interaction within institutions. ${ }^{5}$

(iii) Procedural utility adds a non-instrumental dimension to utility. It focuses on how people are treated due to the processes and institutions under which they live and act. The treatment of people is understood to affect their sense of self and thereby their well-being.

Procedural utility thus can be defined as the hedonic well-being people gain from the quality of treatment in institutionalized processes as it contributes to a positive sense of self.

This psychologically richer concept of utility cannot be neutral with regard to the content of people's preferences, otherwise no testable hypotheses can be derived. In order to study whether the treatment in social interaction and institutions provides procedural (hedonic) utility, preferences have to be filled with basic or intrinsic motives. Great insights on the understanding and the motives

\footnotetext{
2 Daniel Kahneman has coined the term 'experienced utility' for this notion of hedonic utility, in contrast to traditional 'decision utility' (e.g. Kahneman et al. 1997).

${ }^{3}$ Research on subjective well-being in economics takes advantage of extensive previous research in psychology. Subjective well-being is the scientific term for an individual's evaluation of his or her experienced positive and negative affect, happiness or satisfaction with life. With the help of a single question or several questions on global self-reports, it is possible to get indications of individuals' evaluation of their life satisfaction or happiness (Diener et al. 1999, Kahneman et al. 1999). Behind the score indicated by a person lies a cognitive assessment to what extent their overall quality of life is judged in a favorable way (Veenhoven 1993).

${ }^{4}$ An alternative way of describing this is that beliefs about oneself enter the utility function directly (e.g. Akerlof and Dickens 1982).

${ }^{5}$ Non-instrumental human motives of people who are self-aware and who self-reflect have previously entered economic analysis for example in the form of identity (e.g. Akerlof and Kranton 2000), respect, self-esteem and pride (e.g. Khalil 1996, Köszegi 2002a,b and Lea and Webley 1997), self-signaling, goal completion, mastery and meaning (e.g. Loewenstein 1999) or status (e.g. Frank 1985).
} 
of the self have been contributed by psychologists (see e.g. Baumeister 1998 for a survey). In psychology, control and esteem are considered to be the most important motivations of the self, which are strongly linked to happiness (e.g. Campbell 1981). ${ }^{6}$ Within groups, these motives are reflected in people's care about their standing in the group. Group standing is communicated through polite and respectful treatment by authorities (Lind and Tyler 1988). A comprehensive view of most of these aspects is provided in self-determination theory by Deci and Ryan (e.g. 2000). People pursue three main intrinsic motives. First, a desire for autonomy involves the experience to self-organize one's actions or to be causal. Second, a need for relatedness refers to the desire to feel connected to others in love and care. Third, a need for competence refers to the propensity to control the environment and experience oneself as capable and effective. To the extent that interaction between people and decision-making within institutions provide procedural goods serving these innate needs, they contribute to individual well-being, irrespective of instrumental outcomes. $^{7}$

In studying procedural utility we are interested in people's preferences about how they are treated in social interaction and within institutions beyond the outcome that is thereby generated. These preferences about procedures are due to people's striving for a positive sense of self, and their fulfillment contributes to people's general well-being.

\section{The Sources of Procedural Utility}

\section{A. General Remarks}

The sources of procedural utility can be classified into two broad categories.

First, there is the procedural utility people get from institutions as such. People have preferences about how allocative and redistributive decisions are taken. At the level of society, the most important formal systems for reaching decisions are the price system (market), democracy, hierarchy, and bargaining (Dahl and Lindblom 1953). Peoply may gain procedural utility from these institutions because they express judgements about the people involved. For example, a constitution that secures civil liberties like freedom of speech may greatly contribute to people's self-worth. In

\footnotetext{
${ }^{6}$ The underlying theories are manifold and comprise, for instance, people's urge to master their environment for its own sake (White 1959) and of being an origin (DeCharms 1968), people's resistance to loss of control (Brehm 1966) and the reflection of perceived control in more effective behavior and higher positive affects (Bandura 1977, Peterson 1999 and Seligman 1992).

${ }^{7}$ Based on similar reasoning on human functioning there are several categorizations of the dimensions of well-being, for instance, self-acceptance, positive relations with others, autonomy, mastery of the environment, purpose in life and personal growth (Ryff and Keyes 1995), subjective well-being, personal growth and religiosity (Compton 2001) or eudaimonic and hedonic happiness (Waterman 1993).
} 
contrast, a constitution that denies laid off offenders their political rights may be deeply disturbing to the people's sense of self. Institutions thus have a direct effect on individuals' well-being.

Second, it may be argued that procedural utility is involved in the interactions between people. People evaluate actions towards them not only by their consequences, but also by how they feel treated by other persons. Such treatment is importantly shaped by institutions: they provide incentives for people in exchange relationships on how to treat each other in everyday interactions. For instance, labor law and company statutes are shaping the interaction between managers and employees. Or, the organization of the health care system is guiding the relationship between medical suppliers and patients. Institutions thus also have an indirect effect on individuals' wellbeing by motivating and restricting how people are treated.

There is, of course, a smooth transition between the two categories. Institutions on the one hand select and motivate people how to treat their fellow workers, citizens and consumers. On the other hand, people who evaluate institutions, processes or authorities usually base their judgement on the treatment experienced by the specific people involved.

A middle ground between a purely subjective concept of procedural utility and a purely objective institutional approach is possible to find. In can be based, for example, on the large literature on 'procedural fairness' or 'procedural justice', which are the most thoroughly investigated aspects of procedural utility (e.g. Thibaut and Walker 1975, Lind and Tyler 1988). In this large literature, procedural fairness is mainly understood as what individuals perceive to be fair procedures. Nevertheless, it also indicates which objective procedures on average create procedural utility and which do not. Theoretical work by psychologists suggests that procedures are evaluated by the relational information that they convey, such as assessments of impartiality, trustworthiness of superiors and authorities, the extent to which individuals feel they are treated with dignity, and the extent to which individuals are given voice (e.g. Tyler et al. 1997). This allows deriving predictions on when procedures will be seen as more or less fair. In the case of lawsuits, for example, it has been shown that it is well possible to derive which legal procedures are seen as fair and which are not (Lind and Tyler 1988, chapter 5). Although the same 'objective' procedure can be applied differently by different authorities, and the evaluation of a treatment by an individual will always be subjective to some extent, it is thus well possible to derive theoretical hypotheses. Procedures understood in this sense then present an intermediate case between a purely subjective concept of procedural fairness and an institutional approach as described above. ${ }^{8}$

\footnotetext{
8 The literature on procedural fairness finds that procedures are not evaluated in an instrumental sense, i.e. people do not have preferences for fair procedures because they expect desirable outcomes from them (see Thibaut and Walker
} 
The potential applications of procedural utility from institutionalized processes are manifold. They encompass procedural utility from institutions like the market mechanism, democratic decision making, or hierarchy as such, but they also cover procedural differences on a smaller scale, e.g. within an organization or a political system. Procedural utility can be expected to be more pronounced in situations where decisions concerning oneself are at least partly made by others, e.g. by an authority, but in principle it can play a role in any exchange situation where an individual's outcome depends on the behavior of others. The next subsection reviews empirical evidence from a broad range of areas where procedural utility has been shown to matter: the economy, the polity and society, organizations, and law.

\section{B. Economy}

There are many areas in which individuals in their capacity as economic subjects derive procedural utility. Here, two areas are discussed in order to demonstrate the quantitative importance of the utility gained depending on the process used. The first relates to instances where individuals act as consumers, and the second to situations where people act as income earners.

\section{Consumption}

Consumption is probably the area where procedural utility would be least expected: it generally takes place on well functioning markets (individuals can easily substitute) and transactions are focused on outcomes. Nevertheless, procedural utility has also been found to play a role in consumer decisions. First evidence was presented by Kahneman, Knetsch and Thaler (1986). The authors investigate customers' reactions to a situation where the price for a good (snow shovels) was increased in a well-defined excess demand situation (the morning after a large snowstorm). $82 \%$ of the surveyed individuals considered the price increase as unfair, and thus rated a normal functioning of the market mechanism as unacceptable (p. 729). The reaction can be interpreted in terms of procedural utility: People are emotionally negatively affected when they perceive behavior towards them as exploitation because it undermines their status as consumers (who are presumed to be on an equal standing with the suppliers). ${ }^{9}$ Similar results have been found for the US (Konow

1975 on early research interpreting procedural fairness in an instrumental way). Rather, individuals seem to attach an intrinsic value to the process itself, in particular when fairness perceptions are closely linked with notions of agency and group standing (e.g. Lane 1988, Lind and Tyler 1988).

${ }^{9}$ Note that the reaction indeed involves procedural concerns. The authors find that price increases are not always rated as unfair. For example, if firms have to raise prices to protect themselves from losses, e.g. because input prices have gone up, customers generally accept price increases (in contrast to situations where firms try to exploit excess demand). Such differences in acceptance cannot be rationalized with distributional concerns, i.e. outcome considerations. It is noteworthy, however, that the authors themselves do not interpret the differences in procedural terms, but refer to a principle of "dual entitlement": "Transactors have an entitlement to the terms of the reference transaction and firms are 
2001), Switzerland and Germany (Frey and Pommerehne 1993), and Russia (Shiller, Boyocko and Korobov 1991). All these studies put individuals in a situation of excess demand, and find that a consistently high percentage of consumers see a price increase to be an unfair means to overcome the shortage. Thus, the price mechanism seems under these particular circumstances not to be considered as a fair procedure of allocation by the general population in many countries. Anand (2001), applying a similar questionnaire methodology, documents procedural fairness effects for different economic choice situations. If consumers have procedural concerns, this can impose a constraint on profit maximization by suppliers, affecting market equilibrium.

People's concerns with the market mechanism, however, should not be studied in isolation. Rather, different institutions of allocation should be compared. Frey and Pommerehne (1993) contrast the utility individuals attribute to the price system with alternative mechanisms of allocation. When doing this, a somewhat lower share of the respondents (73\%) finds a similar price increase to be unfair. Nevertheless, the market still fares worse than other mechanisms of decision-making. For example, an allocation by "tradition" (first come, first served) is considered by far fewer people to be unfair (24\%), and similarly an allocation by administrative procedures (by the local authorities, $57 \%$ unfair). Only a random allocation (which assigns the goods with equal probability to everybody and has therefore been suggested as a particularly rational allocation mechanism, see Intriligator 1973, Mueller 1978) fares worse than the price system; only to $14 \%$ of the respondents it appears to be fair. Institutions thus seem to play an important role for consumer decisions. People care about their perceived treatment as customers beyond outcome considerations.

Of course, these studies undertaken to evaluate the utility individuals attach to processes can only be a first step. With appropriate care, the findings can be generalized as the studies mentioned consider different situations, and are partly undertaken for different countries. They do, however, not test actual behavior. It cannot be excluded that people react differently when confronted with the same, or a similar, situation in real life. ${ }^{10}$

There is, however, also evidence from real life situations. The issues involved have best been investigated for consumer boycotts. Consumer boycotts are situations where consumers refuse to continue buying from a firm or supplier in response to a behavior they see as inadequate, e.g. an unfair price increase. Marketing research has studied consumer boycotts using different methods, such as historical studies (e.g. Friedman 1995), field studies (e.g. Pruitt and Friedman 1986), and

entitled to their reference profit." (p. 729) Nevertheless, we think that also a concept of "reference terms" would require individuals to have some notion of what a fair process of price increase is. See also Thaler's closely related concept of "transaction utility"(Thaler 1991, p. 33 f.).

${ }^{10}$ Laboratory experiments present an intermediate case. They study behavior, but not in real life, so that the problem of external validity remains. 
survey methods (e.g. Klein, John and Smith 2001). These studies provide a rich picture of boycotts and the motives of consumers to undertake them, which often seem to be non-instrumental. Nevertheless, the studies have difficulties to precisely disentangle the question that interests economists most: do consumers cease to buy from a firm because its behavior constitutes a procedural disutility for them, or just because prices were raised? Tyran and Engelmann (2002) are able to answer this question using an experimental approach. Their study of consumer boycotts in an experimental market shows that "boycotts are mainly called and executed for expressive reasons. That is, consumer boycotts serve to punish sellers for apparently 'unfair' price increases" (p. 3). The authors thus find that boycotts do not primarily serve an instrumental goal. For example, boycotts are undertaken although they often fail to hold down prices and are not profitable for consumers. They are also undertaken irrespective of whether collective action problems prevail (successful boycotts are a public good).

\section{Income earners}

Individuals also enjoy procedural utility in their capacity as income earners. The generation of income can in principle be undertaken under two different decision-making mechanisms: in a hierarchy (as an employee) or on the market (as a self-employed person). Frey and Benz (2002) study whether individuals value these two procedures differently. Looking at individual panel data from the United Kingdom, Germany and Switzerland, they find that self-employed people enjoy higher utility from their work (measured via job satisfaction) than employees, even if important outcomes like pay level, working time, and many others are controlled for. ${ }^{11}$ This can be interpreted in procedural terms: self-employed persons appreciate the autonomy of not being subject to a hierarchy, irrespective of the instrumental outcomes this may produce.

Procedural aspects are also involved for people working within a hierarchy. It has, for example, been shown that workers often resist nominal pay cuts. The resulting downward wage rigidity has macroeconomic consequences because it can cause excess unemployment in recessions (e.g. Bewley 1999, Fehr and Götte 2001). For workers' resistance to pay cuts, not only issues of outcome or distributional fairness seem to be crucial, but also process considerations. It has been shown, for example, that employees' reactions to pay cuts are less averse if this happens through fair processes,

\footnotetext{
${ }^{11}$ Similar results on job satisfaction of self-employed people have been found by Blanchflower and Oswald (1998), Blanchflower, Oswald and Stutzer (2001) and Blanchflower (2000). It is, however, impossible to hold outcomes perfectly constant using such an approach, as many of the job characteristics of self-employed and employed people are not observable. For example, self-employment allows one to be one's own boss; this freedom of choice could also be interpreted as outcome utility (there are less choice restrictions). Certainly, it constitutes a non-monetary benefit. As this non-monetary benefit stems from two fundamentally different decision-making procedures, we prefer to interpret it in procedural terms.
} 
e.g. when management thoroughly and sensitively explains the basis for the pay cuts (Greenberg 1990a). Resistance may also depend on organizational procedures employed by a firm. Hewlett Packard, for example, was able to temporarily lower wages by 20 percent. The employees' support for this measure can be attributed to HP's traditionally strong emphasis on procedural fairness in determining organizational outcomes (Weibel and Rota 2001, p. 180).

\section{Polity and Society}

In their capacity as citizens, people are subject to different political and societal procedures generating procedural utility. This subsection discusses democratic institutions, public good allocation procedures, taxation, and issues of redistribution and inequality.

\section{Democratic participation}

A large literature in the social sciences, especially in psychology, political science and sociology, attributes a positive value to participation, as it enhances individuals' perception of selfdetermination (for an extensive survey see Lane 2000, chapter 13). The rights to participate in political decisions are a crucial characteristic of any democratic institution. They range from voting in elections, launching and voting on referenda, to running for a seat in parliament. Citizens may gain procedural utility from such participation rights over and above the outcome generated in the political process, because they provide a feeling of being involved and having political influence, as well as a notion of inclusion, identity and self-determination. By being able to participate, citizens may feel that the political sphere takes their wishes seriously into account in a fair political process; if participation is restricted, they may feel alienation and apathy towards the political institutions installed.

Frey and Stutzer (2002b) try to empirically identify such procedural utility from political participation rights, basing their analysis on the fact that the status of being a national fundamentally differs from that of being a foreigner. Nationals have the right to vote and to participate in political decision-making, while foreigners do not have these rights. Nationals should thus derive more utility from political participation rights than foreigners if they enjoy procedural utility.

This hypothesis is tested econometrically using a survey based on more than 6,000 interviews with residents of Switzerland. Data for Switzerland is studied because there exists a unique variation in the political participation rights among citizens. In addition to elections, citizens have access to direct democratic instruments (initiatives, referenda) which differ substantially from canton to 
canton. As a proxy measure for utility, an index of reported subjective well-being is used as the dependent variable. The estimated overall utility effect from more extended political participation rights, as reflected in reported life satisfaction, is in itself sizeable. Citizens, as well as foreigners, living in jurisdictions with more developed political participation rights enjoy higher levels of subjective well-being. The positive effect on reported satisfaction with life is, however, smaller for foreigners, reflecting their exclusion from procedural utility. The positive effect of participation rights is about three times larger for the citizens than it is for the foreigners, i.e. a major part of the welfare gain from the favorable political procedures seems to be due to procedural utility. The results hold ceteris paribus, i.e. when a large number of determinants or correlates of subjective well-being (in particular socio-demographic characteristics, employment status and household income) are controlled for.

\section{Public good allocation}

One of the most pressing problems of government policy is to find ways and means to overcome the resistance of individuals to so-called NIMBY-projects. They refer to public undertakings generally considered important and desirable, such as finding suitable locations for hospitals for the mentally deranged or handicapped, for airports or for nuclear waste. The term NIMBY indicates that in many instances individuals strongly support such projects - except that they do not want to see them in their neighborhood (hence 'Not In My Back Yard'). ${ }^{12}$ Traditional economic theory offers a straightforward solution to this problem. As in the aggregate, the benefits are larger than the costs, the prospective gainers must be taxed and the revenue must be redistributed to the prospective losers. The most elegant and efficient procedure is to undertake an appropriate auction (see Kunreuther and Kleindorfer 1986, O’Sullivan 1993). Yet it has turned out that the use of the price system in that case meets with much resistance, and that the procedure based on the price system indeed rarely, if ever works. The individuals expecting to lose from a particular siting project tend to consider the monetary compensation offered to them to be a bribe to which they fundamentally object. Bribing disregards people's sense of self as decent citizens and thus generates negative procedural utility. Indeed, it has been empirically demonstrated (Frey and Oberholzer-Gee 1997) that offering a monetary compensation to the inhabitants of the nearby village to induce them to accept the site leads to a counterproductive reaction: the support for the site falls instead of increases. If instead the compensation is offered in a way addressing the concerns of the individuals affected, the proposed project has a better chance of being accepted. Thus, for example, if people

\footnotetext{
${ }^{12}$ See Rabe (1994), Gerrard (1994) and Easterling and Kunreuther (1995) on the problems associated with NIMBYprojects.
} 
fear that the location of a nuclear refuse plant produces health risks they should be offered improved medical facilities; if they fear the noise produced by an airport they should be helped to insulate their homes. Such material compensation along a predetermined dimension is inefficient according to received welfare theory. Individuals thus seem to be prepared to accept a worse outcome if they feel that the process does justice to their concerns.

Institutional differences also play a role. Oberholzer et al. (1995) investigated the acceptability of different decision making procedures for siting a noxious facility. The 900 persons interviewed ranked procedures in the following order: negotiations (bargaining) were seen by $79 \%$ as an acceptable procedure of siting, 39\% found referenda (democracy) to be acceptable, $32 \%$ a decision by lottery, and only few saw the price system as an acceptable procedure (20\% in the form of willingness to accept, and $4 \%$ in the form of willingness to pay). ${ }^{13}$

\section{The treatment of taxpayers}

Individuals may value procedural differences in their role as taxpayers. This is an aspect that has been completely neglected by economic research on taxpayer behavior. Public economics or neoclassical public finance uses a model of taxpayer behavior (initiated by Allingham and Sandmo 1972) that is based only on outcome considerations: the extent of tax evasion depends negatively on the probability of being caught and the size of the punishment if caught (see Andreoni, Erard and Feinstein 1998: 824 - 835; and Slemrod and Yitzhaki 2002 for overviews).

From an empirical point of view, this model is faced with two major problems. First, it is difficult, if not impossible, to account for the level of tax evasion. In view of the low deterrence applied in most countries, taxpayers should evade much more than they actually do, i.e. compliance is too high. For the United States, Alm, McClelland and Schulze (1992: 22) argue: "A purely economic analysis of the evasion gamble implies that most individuals would evade if they are 'rational', because it is unlikely that cheaters will be caught and penalized“. Second, the econometric parameter estimates are unsatisfactory. Often, they turn out not to be statistically significant, and sometimes their signs are inconsistent with the theory (see e.g. Pommerehne and Weck-Hannemann 1996).

Thus, new insights on tax compliance and tax evasion may be gained by taking issues of procedural fairness into account. Taxpayers may respond, for example, in a systematic way to how the tax

\footnotetext{
${ }^{13}$ A more detailed analysis revealed that "acceptability" was seen by respondents as consisting of three components: "security", "local influence", and "fairness". It transpired that the ranking in terms of "fairness" exactly mirrored the above given ranking in terms of acceptability. Thus, the results can clearly be interpreted in procedural terms; it is not only the implication for the outcomes that makes people find a procedure as more acceptable or not.
} 
authority treats them: when the tax officials treat them with respect and dignity, their willingness to pay taxes may be supported or even raised. In contrast, when the tax officials consider taxpayers purely as 'subjects' who have to be forced to pay their dues, the taxpayers may respond by actively trying to avoid taxation.

Using a sample of Swiss cantons in the years 1970-1995, Feld and Frey (2002) and Frey and Feld (2002) find econometric evidence that taxpayers act according to these predictions. Individuals seem to experience higher utility when they are more respectfully treated in the taxation process, and are thus more willing to pay their taxes. Moreover, tax authorities in Switzerland behave as if they were aware of the reaction of taxpayers to being treated with respect or not. Deterrence is only one of the motivational forces used by the authorities; often, they rely on respectful procedures of tax collection.

\section{Redistribution and inequality}

Social inequality is a phenomenon that many individuals and governments are concerned with. People's unhappiness with inequality often depends on the extent to which the income distribution in a society is unequal, and also on their own position in this distribution. However, this may not be all. A given social inequality can also be judged with respect to the societal processes that brought it about. For example, if social processes provide everyone with a fair chance to 'make it', inequality might be seen as less of a problem than when social processes are biased and unfair. Social inequality may thus not only be a problem of outcome distribution, but also of fair social procedures.

Alesina, Di Tella and MacCulloch (2001) and Alesina and LaFerrara (2001) provide empirical evidence that underscores such a role of social processes. Alesina, Di Tella and MacCulloch (2001) find that there is a large negative effect of income inequality on happiness in Europe, but not in the US. The authors argue that it is not a difference in inequality aversion that explains this result, i.e. that Europeans would prefer more equal societies. Rather, it seems that it is the lower social mobility in Europe that makes its citizens more concerned with inequality. Similar results are reported by Alesina and LaFerrara (2002) who study individuals' preferences for redistribution across US states. They find that support for redistributive policies is not only determined by an individuals' income position (and many other determinants), but also strongly influenced by the extent of social mobility in a state. ${ }^{14}$ Higher social mobility lowers people's support for

\footnotetext{
${ }^{14}$ The authors derive measures of social mobility for each state and year from 1978-1991 using income data from the General Social Surveys and the Panel Study of Income Dynamics. The two main measures they use are 'expected future
} 
redistribution. This, of course, can be interpreted in outcome terms: if the probability that someone gets rich is high, an individual will be less likely to support redistributive policies, because he or she might become a net payer. ${ }^{15}$ But social mobility can as well be interpreted in procedural terms: if people see that society offers equal opportunities, on average and in an objective sense of actual income mobility, they may be less concerned with inequality because they see social processes as fair. Indeed, Alesina and LaFerrara report evidence that lends support to this second interpretation. Although the extent of social mobility on average lowers support for redistribution, its effect substantially depends on individuals' fairness perceptions of the mobility process. Those who feel that equal opportunities really exist are less concerned with inequality when mobility is higher, i.e. they judge the 'objective condition' of higher mobility as indeed offering everybody a chance and thus withdraw their support for redistribution. In contrast, those who see social mobility generally as a biased process do not lower their redistributive support in the light of higher mobility, probably because they feel that even objectively higher mobility generates opportunities only for some and not for all.

\section{Organizations}

Organizations are the field where aspects of procedural utility have been most intensively studied. In hierarchies, many decisions are taken in an 'authoritarian' way. Under such circumstances, individuals' concerns with procedures must be expected to be high. The literature on procedural fairness or justice in organizations is so large that there already exist meta-analyses (e.g. CohenCharash and Spector 2001). The studies consistently find that concerns for procedural fairness are a highly relevant and widespread phenomenon in the employment relationship. It has been shown to matter for employees' behavior, satisfaction, and attitudes in areas like change (mergers and acquisitions, layoffs, restructuring, strategic planning) and human resources (personnel selection, performance evaluation, and compensation, see Konovsky 2000 for an overview). Procedural aspects that researchers have identified as important include organizational policies and rules, e.g. providing advance notice for decisions and opportunities for voice (see Greenberg 1990b and Lind and Tyler 1988), but they also encompass the interpersonal treatment of people (Bies and Moag 1986). Individuals have been found to generally value fair procedures over and above organizational outcomes. Procedural fairness effects prevail when individual outcomes as well as aspects of distributional fairness are controlled for in the analysis. Thus, procedural utility is without doubt a relevant part of what individuals value when working in organizations.

income' and 'relative mobility', which indicates the probability that an individual in a certain income decile will move above mean income a year later. 


\section{E. Law}

Similar to organizations, procedural aspects are expected to be important in law because people often are subjected to decisions by authorities. Law is thus an area where procedural fairness has been well studied. Many studies find that people react adversely to unfair legal procedures, irrespective of the objective judgment made by a court. Unfair procedures lead individuals to rate the legitimacy of authorities and their satisfaction with a trial lower, and it also affects subsequent compliance behavior (see Tyler 1997 for an overview).

One study might be summarized as an example, because it investigates real life behavior and thus will be of most interest to economists. Lind et al. (1993) study the acceptance of awards from courtordered arbitration by real life litigants, which included corporate and individual litigants in Federal Courts. The authors find that litigants who judge the arbitration process as fair are much more likely to accept the court-ordered award (irrespective of the objective outcome). The decision to go on to have a formal trial was most strongly influenced by procedural fairness considerations. This is remarkable, as the disputes considered involved amounts of money of up to US\$800'000. The objective size of the award also predicted acceptance, although to a much lesser extent. Thus, the study shows that utility from procedures plays a role in lawsuits over and above outcome utility.

\section{Relationships Between Procedural and Outcome Utility}

Given that procedural utility exists, how can it be fruitfully integrated into the existing economic approach? This section explores theoretical relationships between procedural utility and standard outcome utility.

\section{Are procedures and outcomes independent of each other?}

If processes generate utility, a first question is how this changes our understanding of the relationship between processes and outcomes. This is of particular importance for the study of procedures which are employed at the level of society (decision-making mechanisms like the market, democracy, or hierarchy) and the evaluation of the outcomes they produce. The question touches on fundamental issues of social choice, i.e. the study of how a society can sensibly arrive at aggregate social welfare judgements. The following thoughts draw mainly on Sen (1995), who brilliantly summarizes the issues in his presidential address to the American Economic Association (see also Sugden 1981, 1986).

\footnotetext{
${ }^{15}$ This is the interpretation favored by Alesina and co-workers.
} 
Most of the economic (and also political science) approaches to social welfare are purely outcomeoriented. The most extreme form is probably embodied in the 'New Welfare Economics'. Its criterion for social decision-making is the Pareto principle: a social improvement is achieved (e.g. by a public project, regulation or deregulation) if at least the utility of one person is increased while nobody's utility is reduced. Procedures do not play any genuine role in this approach, and certainly it attaches no intrinsic value to procedural aspects such as whether a given outcome is achieved by e.g. preserving fundamental rights or freedoms of individuals or not. The same criticism can be made with respect to the Public Choice approach, or Institutional Economics more generally. Although these approaches are much concerned with the study of procedures, they still are mainly interested in them for the outcomes they produce. If, for example, different democratic decision making procedures are studied or production in hierarchies is compared to markets, institutions are always evaluated with respect to the outcomes they produce. Thus, these approaches disregard a potentially large source of human well-being by not taking experienced pleasures and displeasures of processes into account. As Sen (1995) puts it: , [...] it is hard to be convinced that we can plausibly judge any given utility distribution ignoring altogether the process that led to that distribution (attaching, for example, no intrinsic importance whatever to whether a particular utility distribution is caused by charity, or taxation, or torture)“ (p. 12). Thus, judgements on social welfare outcomes should not be made independently of the procedures by which a society arrives at these outcomes; rather, the procedural utility stemming from different socio-economic decision mechanisms should seriously be taken into account. ${ }^{16}$

Implicitly, this view is already present in some parts of economic analysis. Economists often seem to favor markets as allocation mechanisms not only because markets produce better outcomes, but also because markets institutionalize a favored treatment of trading partners in interaction. An example is the support of market systems by liberal economists like Buchanan (1986, p.22, cit. in Sen, 1995): „To the extent that voluntary exchange among persons is valued positively while coercion is valued negatively, there emerges the implication that substitution of the former for the latter is desired, on the presumption, of course, that such substitution is technologically feasible and is not prohibitively costly in resources“ (p. 11). It is, however, an empirical question whether and under what conditions individuals gain procedural utility from market mechanisms, or whether they attach, as other economists would argue, rather an intrinsic value to egalitarian decisionmechanisms such as democracy.

\footnotetext{
${ }^{16}$ This is also reflected in the famous 'Impossibility of the Paretian Liberal' (Sen, 1970): even minimal procedural requirements of personal liberty (which can be interpreted as sources of procedural utility) can conflict with principles of outcome orientation like Pareto superiority.
} 
In contrast, can procedures be reasonably evaluated ignoring the outcomes they produce? An affirmative extreme position in this respect is taken by libertarians such as Nozick (1974). In his treatment of ,right rules', personal liberties as well as rights of property are given a high intrinsic value almost irrespective of the outcomes a system based on these rights and liberties produces. Nevertheless, even a pure procedural approach has to consider the possibility that the consequences of such a liberal society might be catastrophic: „Indeed, it can be shown that even gigantic famines can actually take place in an economy that fulfills all the libertarian rights and entitlements specified in the Nozick system“ (Sen, 1995, p.12).

In summary, there are good reasons for taking procedural and outcome concerns simultaneously into consideration when analyzing socio-economic decision mechanisms. It follows that the relative importance of 'right procedures' and 'good outcomes' is most effectively studied within the same empirical framework for individual well-being.

\section{Is there a trade-off between process and outcome concerns?}

Evidence discussed in section III has indicated that there are institutional arrangements with which process concerns and outcome concerns can be satisfied simultaneously: for example, in the case of democratic participation rights, the procedure seems to produce positive procedural utility as well as better outcomes. ${ }^{17}$ This can be seen as a fortunate instance where a socio-economic decision mechanism is valued positively by individuals as a desirable process as well as for its good outcomes. A more general analysis, however, has obviously to take into account that there is often a trade-off between procedural and outcome concerns. Sen's Impossibility of a Paretian Liberal, for example, shows that individual liberty rights and criteria of social welfare maximization often stand in contradiction to each other. This section explores this aspect on a more individual level, moving the analysis away from social choice considerations.

In a simple microeconomic analysis, procedural utility enters the utility function in addition to any instrumental arguments of utility. Thus it is possible to trade-off procedural utility against the other arguments. This can be practiced in the equilibrium approach of compensating variation: if, for example, workers intrinsically value a specific organizational procedure, they should be willing to accept a lower wage (a worse instrumental outcome) in order to work in an organization that is applying it. There is, however, not a simple trade-off, as outcome and process utility are not perfectly separable.

\footnotetext{
${ }^{17}$ See Frey and Stutzer (2002b). This holds at least for a certain range of democratic participation possibilities. It is quite conceivable that an extreme form of direct democracy has welfare costs by imposing such high transaction costs
} 
Psychological research on procedural utility emphasizes the subtle cross-effects between outcome and process evaluations (and almost completely neglects equilibrium considerations). In general, the quality of procedures is seen as more important when outcomes are bad, and less relevant when outcomes are good. An area where such trade-offs have been thoroughly studied are lawsuits (see Lind and Tyler 1988: chapter 4). Many studies find that people react adversely to unfair judicial procedures especially when the result of the lawsuit is bad for them; when the outcome is good, individuals do not care so much about procedural qualities (although they still do to some extent). ${ }^{18}$

However, unfair procedures are sometimes self-protecting. Consider for instance the case of an organizational procedure like pay determination. If you get less pay in a year because your performance was weak, but the procedure of pay determination was extremely fair, would you really be more satisfied with your pay? In part yes, because you would still favor a fair over an unfair procedure. But there is a countervailing effect. If a procedure is fair, an unfavorable outcome has to be attributed to oneself; if it is unfair, one can blame the authority for the bad outcome (Schroth and Shah 2000, see also Brockner and Wiesenfeld 1996). This attribution effect predicts a complementary relationship between processes and outcomes: fair procedures are more valued when outcomes are good. ${ }^{19}$ The net relationship between procedural and outcome utility then depends on the relative strength of the substitutive and complementary effects. The two effects have been studied, for instance, in a representative sample of British workers for the case of procedural utility from pay determination procedures (Benz and Stutzer 2002). It is found that i) workers report higher pay satisfaction when they are involved in compensation questions and ii) the gains in pay satisfaction are of equal magnitude for workers who get a high wage as for those who get a relatively low wage.

To understand the trade-offs between outcome and process concerns attribution theory enters into the picture. Attribution theory can help to specify under which conditions particular cross-effects prevail. There are interesting implications, and theoretical work by economists integrating attribution phenomena into models of human behavior has already been undertaken (see e.g. Falk and Fischbacher 2000 and Rabin 1993 on intentions). Empirically, attribution can well be tractable. In some situations, attribution can be unambiguous (for an experiment of this kind, see Falk, Fehr and Fischbacher 2000). In others, it might be proxied, for example, by religious orientation. One can hypothesize that non-religious persons are more likely to attribute outcomes to themselves or to

on a society that economic activity is seriously damaged. Then, the trade-off between procedures and outcomes reemerges.

${ }^{18}$ In economics, these cases would correspond to a comprehensive utility function in which outcome and process are strategic substitutes.

${ }^{19}$ The technically more precise description in economics would be one in terms of strategic complements. 
secular society, while religious persons would see them more as a matter of fate or godly will. MacCulloch and Pezzini (2002) offer interesting related evidence with respect to citizens' support for revolutions in 61 countries over the years from 1981-1997. First, they find an effect which can be interpreted in procedural terms: revolutionary support by individuals is significantly lower in politically free countries, even when GDP per capita, GDP growth, individual income position and many more outcome variables are controlled for. Second, they find that religious persons are indeed less likely to support revolt. It is worth noting, however, that the interaction effect between political freedom and religiosity turns out to be the opposite of what one would expect: religious people react even more strongly to bad procedures (no political freedom) than non-religious persons. Nevertheless, the results indicate that empirical tests of trade-offs between procedural and outcome concerns and their interaction with attribution issues are well feasible.

\section{Does the importance of procedural utility depend on the context of action?}

If procedural utility exists, can we indicate under what conditions it will be more important, and under what circumstances it will be less important? A natural approach for economists to answer this question would be to consider the choice alternatives individuals have at hand. Procedural utility always carries the notion that people are subject to a procedure; to some extent, decisions are made by others, and cannot be taken by individuals themselves. A simple hypothesis following from this is that procedural utility is more important when individuals find it more costly to switch to alternatives. Exit can be restricted by law, or it may involve high transaction costs. In such situations, individuals will be especially concerned with the quality of procedures.

This prediction corresponds nicely with empirical findings (see also section III). Procedural utility has been identified to be an important aspect in lawsuits; clearly, individuals have very limited possibilities of opting out when involved in a lawsuit. Similarly, individuals are particularly concerned with the quality of their treatment when faced with a state monopoly. Moving to another jurisdiction often involves high transaction costs. ${ }^{20}$ This can explain why people intrinsically value the possibility to participate in democratic decision-making, or fair procedures when they are dealing with the public administration. Procedural quality has also been shown to matter in organizations, where workers often face considerable transaction costs to move to another workplace. In contrast, procedural utility can be expected to play a lesser role on markets, because individuals can more easily switch to alternatives.

\footnotetext{
${ }^{20}$ These costs depend, of course, on the nature of the political system. In systems of fiscal federalism, exit costs are lower than in centralized countries.
} 
The analysis indicates that a host of testable hypotheses on the importance of procedural utility in different institutional settings can be derived using a simple approach of costly choice alternatives. An application will be given with respect to customer markets. Although economic analysis often treats markets as perfect, in reality firms often have some monopoly power (if only because customers face search costs). A straightforward hypothesis then is that customers should have greater procedural concerns - i.e. on their treatment as consumers - when they find themselves in a monopoly situation than when possibilities to switch to another supplier are relatively easy. Evidence reported in Kahneman, Knetsch and Thaler (1986) supports this prediction. As mentioned before, the authors investigate customers' reactions to a situation where the price for a good was increased in a well-defined excess demand situation. $82 \%$ of the surveyed individuals considered the price increase to be unfair (p. 729). However, when individuals were put in another situation where they had explicitly more substitution possibilities, a similar price increase was seen as unfair only by $63 \%$ of the people interviewed (p. 734). Similar results have been found by Frey and Pommerehne (1993). Their results show that raising prices in response to a demand increase in a market is more accepted when choice alternatives are less costly, e.g. if the demand shift occurs at predictable intervals, if customers are previously informed and thus have time to look for alternatives, or if alternative suppliers or products exist.

\section{Policy Consequences and Conclusions}

Empirical evidence supports the existence and relevance of procedural utility in many areas of the economy and society. Moreover, procedural utility can be theoretically integrated into economic models. We wish to conclude by indicating some implications for economic theory and policy.

Integrating procedural utility into economics both makes it richer and allows taking into account phenomena otherwise difficult or impossible to explain. To some extent, procedural fairness has been acknowledged in economic psychology or behavioral economics, although most attention has been paid to integrating outcome fairness into individual utility functions (Bolton and Ockenfels 1999, Fehr and Schmidt 1999, Konow 2002).

Institutions can be looked at as not only producing particular outcomes but also as framing decision-making procedures. The market, under well-known conditions, leads to efficient outcomes but moreover produces procedural utilities and disutilities. The use of market prices to equilibrate supply and demand is sometimes vigorously opposed by the individuals involved. In particular, consumers perceive raising prices to ration demand to be an unfair and disrespectful treatment and prefer other decision-making mechanisms to fulfil this task. While such reactions have often been 
observed, economists solely concerned with the narrowly consequentialist aspects of the price system are ill equipped to deal with this empirical phenomenon. Yet it is important to see that every decision-making mechanism has its advantages and disadvantages with respect to the procedural utility produced. The random allocation system, for instance, may often fare well with respect to outcome utility or fairness, but has often been rejected by the persons involved because of the procedural disutility produced. When economists suggest policy actions and are concerned with their acceptability they must also pay attention to the procedural utilities attached to the various decision-making systems.

Another aspect enriching economic theory relates to the procedural utility produced by individuals' possibilities to participate in social and economic decision-making. The rights to participate in political and economic decisions are important characteristics of modern societies. In politics, participation rights range from voting in elections and referenda, to running for a seat in parliament. In the economy, participation rights may range from exerting influence with respect to one's work place and work organization to full scale co-determination in the management of the firms. Individuals gain procedural utility from such participation rights over and above the outcome generated, because they provide a feeling of being involved and having influence, as well as a notion of inclusion, identity and self-determination. Formal institutions of worker participation have been enshrined in the constitutions of some countries (the primary example being Germany with its extensive co-determination rights) but economists have mainly analyzed its instrumental effects on outcomes, in particular on productivity and wages. But this should not be all: the purely procedural aspects also play a substantial role, which has to be taken into account.

Procedural utility also has major consequences for economic policy.

In consumption procedural utility plays a role in decisions. In so far as individuals consider price increases by suppliers as unfair profit maximization by suppliers is constrained which in turn affects market equilibrium. An extreme form are boycotts where consumers refuse to continue buying from a supplier. The consumers' goals implied often are non-instrumental. Boycotts are undertaken although they frequently fail to hold down prices and impose losses on consumers. Such behavior is difficult to understand in purely outcome terms. Consumption policy should be aware of the expressive function of boycotts. Often, the solution to consumers' grievances is not only to improve a good or service but to be taken seriously by the suppliers.

Individuals also enjoy procedural utility in their capacity as income earners. Self-employed persons value the autonomy of not being subjected to a hierarchy, irrespective of the instrumental outcomes this may produce. Procedural aspects are also involved for people working within a hierarchy. 
Workers tend to resist pay cuts, not only because of outcome or distributional concerns but also for procedural considerations. This has immediate consequences for employment and wage policy. Procedural fairness matters for employees' behavior, satisfaction, and attitudes in many different areas such as mergers and acquisitions, layoffs, restructuring, strategic planning, personnel selection, performance evaluation, and compensation.

One of the most pressing problems of government policy is to find ways and means to overcome the resistance of individuals to public undertakings generally considered important and desirable. Traditional economic theory's solution to this problem is to tax prospective gainers and to redistribute the revenue to the prospective losers. Yet this use of the price system has met with much resistance. The individuals expecting to lose from a particular siting project tend to consider the monetary compensation offered to them as a bribe to which they fundamentally object. A more effective policy is to directly address the concerns of the individuals affected This demonstrates the importance that procedures exert on individuals' utility where issues of public good allocation are concerned.

Individuals also value procedural aspects in their role as taxpayers. The extent to which they evade taxes does not only depend on outcome aspects such as the tax rate, the probability of being caught and the size of the punishment, but also on how respectfully they feel treated by the tax authorities. New insights on tax compliance and tax evasion may be gained by taking issues of procedural fairness into account. The level of taxation and deterrence thus are not the only policy variables available. To the extent that individuals experience higher utility when respectfully treated in the taxation process they are more willing to pay their dues.

Social inequality is a phenomenon that many individuals and governments are concerned with. People's unhappiness with the existing income distribution depends on their own relative position. Moreover, a given social inequality is also judged with respect to the societal processes that brought it about. If everyone gets a fair chance to do well inequality is less of a problem. In contrast, when social processes are perceived to be biased conflicts over income distribution tend to erupt. The high economic and social cost of such strife can be mitigated or evaded if an effort is made to keep the underlying process as fair as possible, in particular to ease upward social mobility

On the basis of these considerations it seems justified to state that taking procedural utility seriously is important both in economic theory and policy. 


\section{References}

Akerlof, George A. and William T. Dickens (1982). The Economic Consequences of Cognitive Dissonance. American Economic Review 72(3): 307-319.

Akerlof, George A. and Rachel E. Kranton (2000). Economics and Identity. Quarterly Journal of Economics 115(3): 715-753.

Alesina, Alberto and Eliana LaFerrara (2001). Preferences for Redistribution in the Land of Opportunities. NBER Working Paper No. 8267.

Alesina, Alberto, Di Tella, Rafael and Robert MacCulloch (2001). Inequality and Happiness: Are Europeans and Americans Different? NBER Working Paper No. 8198.

Allingham, Michael G. and Agnar Sandmo (1972). Income Tax Evasion: A Theoretical Analysis. Journal of Public Economics 1 (3-4), 323-338.

Alm, James, Gary H. McClelland and William D. Schulze (1992). Why Do People Pay Taxes? Journal of Public Economics 48(1): 21-38.

Andreoni, James, Brian Erard and Jonathan Feinstein (1998). Tax Compliance. Journal of Economic Literature 36(2): 818-860.

Anand, Paul (2001), Procedural Fairness in Economic and Social Choice: Evidence from a Survey of Voters. Journal of Economic Psychology 22(2): 247-270.

Bandura, Albert (1977). Self-Efficacy: Toward a Unifying Theory of Behavior Change. Psychological Review 84: 191-215.

Baumeister, Roy F. (1998). The Self. In: Daniel T. Gilbert, Susan T. Fiske and Gardner Lindzey (eds). The Handbook of Social Psychology, vol. 1. New York and Oxford: Oxford University Press.

Becker, Gary S. (1976). The Economic Approach to Human Behavior. Chicago: Chicago University Press.

Benz, Matthias and Alois Stutzer (2002). Do Workers Reap Procedural Utility? Working Paper No. Institute for Empirical Research in Economics, University of Zurich.

Bewley, Truman E. (1999). Why Wages Don't Fall During a Recession. Cambridge and London: Harvard University Press.

Bies, R. J. and J.S. Moag (1986). Interactional Justice: Communication Criteria of Fairness. In: R. J. Lewicki, B. H. Sheppard and B. H. Bazerman (eds.). Research on Negotiation in Organizations, vol. 1. Greenwich: JAI Press: 43-55.

Blanchflower, David G. (2000). Self-employment in OECD Coutries. Labour Economics 7(5): 471505.

Blanchflower, David G. and Andrew Oswald (1998). What Makes an Entrepreneur? Journal of Labor Economics 16(1): 26-60.

Blanchflower, David G., Oswald, Andrew J. and Alois Stutzer (2001). Latent Entrepreneurship Across Nations. European Economic Review 45(4-6): 680-691.

Brehm, Jack W. (1966). A Theory of Psychological Reactance. New York: Academic Press.

Brockner, Joel and Batia M. Wiesenfeld (1996). An Integrative Framework for Explaining Reactions to Decisions: Interactive Effects of Outcomes and Procedures. Psychological Bulletin 120(2): 189-208.

Buchanan, James M. (1986). Liberty, Market and the State. Brighton: Wheatsheaf.

Campbell, Angus (1981). The Sense of Well-Being in America. New York: McGraw-Hill. 
Cohen-Charash, Yochi and Paul E. Spector (2001). The Role of Justice in Organizations: A MetaAnalysis. Organizational Behavior and Human Decision Processes 86(2): 278-321.

Compton, William C. (2001). Toward a Tripartite Factor Structure of Mental Health: Subjective Well-Being, Personal Growth, and Religiosity. Journal of Psychology 135(5): 486-500.

Dahl, Robert A. and Charles E. Lindblom (1953). Politics, Economics and Welfare: Planning and Politico-Economic Systems Resolved into Basic Social Processes. Harper: New York.

DeCharms, Richard (1968). Personal Causation. New York: Academic Press.

Deci, Edward L. and Richard M. Ryan (2000). The "What" and "Why" of Goal Pursuits: Human Needs and the Self-determination of Behavior. Psychological Inquiry 11(4): 227-268.

Diener, Ed, Eunkook M. Suh, Richard E. Lucas and Heidi L. Smith (1999). Subjective Well-Being: Three Decades of Progress. Psychological Bulletin 125(2): 276-303.

Easterling, Douglas H. and Howard Kunreuther (1995). The Dilemma of Siting a High-Level Nuclear Waste Repository. Boston: Kluwer.

Falk, Armin and Urs Fischbacher (2000). A Theory of Reciprocity. Working Paper No. 6. Institute for Empirical Research in Economics, University of Zurich.

Falk, Armin, Ernst Fehr and Urs Fischbacher (2000). Testing Theories of Fairness - Intentions Matter. Working Paper No. 63. Institute for Empirical Research in Economics, University of Zurich.

Fehr, Ernst and Lorenz Götte (2001). Robustness and Real Consequences of Nominal Wage Rigidity. Working Paper No. 44. Institute for Empirical Research in Economics, University of Zurich.

Feld, Lars P. and Bruno S. Frey (2002). Trust Breeds Trust: How Taxpayers Are Treated. Economics of Governance 3: 87-99.

Frank, Robert H. (1985). Choosing the Right Pond. New York: Oxford University Press.

Frey, Bruno S. (1999). Economics as a Science of Human Behavior. Second, extended edition, Dordrecht: Kluwer.

Frey, Bruno S. and Alois Stutzer (2002a). What Can Economists Learn from Happiness Research? Journal of Economic Literature 40(2): 402-435.

Frey, Bruno S. and Alois Stutzer (2002b). Beyond Outcomes: Measuring Procedural Utility. Berkeley Olin Program in Law \& Economics, Working Paper No. 63.

Frey, Bruno S. and Felix Oberholzer-Gee (1997). The Cost of Price Incentives: An Empirical Analysis of Motivation Crowding-Out. American Economic Review 87(4): 746-755.

Frey, Bruno S. and Lars P. Feld (2002). Deterrence and Morale in Taxation: An Empirical Analysis. Mimeo. Institute for Empirical Research in Economics, University of Zurich.

Frey, Bruno S. and Matthias Benz (2002). Being Independent is a Great Thing. Mimeo. Institute for Empirical Research in Economics, University of Zurich.

Frey, Bruno S. and Werner W. Pommerehne (1993). On the Fairness of Pricing - An Empirical Survey among the General Population. Journal of Economic Behavior and Organization 20(3): 295-307.

Friedman, M. (1995). American Consumer Boycotts in Response to Rising Food Prices: Housewives' Protests at the Grassroots Level. Journal of Consumer Policy 18(1): 55-72.

Gerrard, M.B. (1994). Whose Backyard, Whose Risk: Fear and Fairness in Toxic and Nuclear Waste Siting. Cambridge, MA: MIT Press.

Greenberg, Jerald (1990a). Employee Theft as a Reaction to Underpayment Inequity: The Hidden Cost of Pay Cuts. Journal of Applied Psychology 75(5): 561-570. 
Greenberg, Jerald (1990b). Organizational Justice: Yesterday, Today, and Tomorrow. Journal of Management 16(2): 399-432.

Harsanyi, John C. (1993). Normative Validity and Meaning of von Neumann-Morgenstern Utilities. In: Ken Binmore, Alan Kirman and Piero Tani (Eds.). Frontiers of Game Theory. Cambridge, MA und London: MIT Press: 307-320.

Kahneman, Daniel (1999). Objective Happiness. In: Daniel Kahneman, Ed Diener and Norbert Schwarz (eds). Well-Being: The Foundation of Hedonic Psychology. New York: Russell Sage Foundation: 3-25.

Kahneman, Daniel, Ed Diener and Norbert Schwarz (eds) (1999). Well-Being: The Foundation of Hedonic Psychology. New York: Russell Sage Foundation.

Kahneman, Daniel, Jack L. Knetsch and Richard H. Thaler (1986). Fairness as a Constraint on Profit Seeking: Entitlements in the Market. American Economic Review 76(4): 728-741.

Kahneman, Daniel, Peter P. Wakker and Rakesh Sarin (1997). Back to Bentham? Explorations of Experienced Utility. Quarterly Journal of Economics 112(2): 375-405.

Khalil, Elias L. (1996). Respect, Admiration, Aggrandizement: Adam Smith as Economic Psychologist. Journal of Economic Psychology 17(5): 555-577.

Klein, Jill G., John, Andrew and Smith, N. Craig (2001): Exploring Motivations for Participation in a Consumer Boycott. Centre for Marketing Working Paper 01-701, London Business School.

Konovsky, Mary A. (2000). Understanding Procedural Justice and its Impact on Business Organizations. Journal of Management 26(3): 489-511.

Konow, James (2001). Fair and Square: The Four Sides of Distributive Justice. Journal of Economic Behavior and Organization 46(2): 137-64.

Konow, James (2002). Which Is the Fairest One of All?: A Positive Analysis of Justice Theories. Mimeo. Loyola Marymount University, Los Angeles.

Köszegi, Botond (2002a). Ego Utility and Information Acquisition. Mimeo. University of California at Berkeley.

Köszegi, Botond (2002b). Ego Utility, Overconfidence, and Task Choice. Mimeo. University of California at Berkeley.

Lane, Robert E. (1988). Procedural Goods in a Democracy. Social Justice Research 2(3): 177-192.

Lane, Robert E. (2000). The Loss of Happiness in Market Economies. New Haven and London: Yale University Press.

Lazear, Edward P. (2000). Economic Imperialism. Quarterly Journal of Economics 115(1): 99-146.

Le Menestrel, Marc (2001). A Process Approach to the Utility for Gambling. Theory and Decision 50(3): 249-262.

Lea, Stephen E. and Paul Webley (1997). Pride in Economic Psychology. Journal of Economic Psychology 18(2-3): 323-340.

Lind, E. Allen, Carol T. Kulik, Maureen Ambrose and Maria V. de Vera Park (1993). Individual and Corporate Dispute Resolution: Using Procedural Fairness as a Decision Heuristic. Administrative Science Quarterly 38(2): 224-251.

Lind, E. Allan and Tom R. Tyler (1988). The Social Psychology of Procedural Justice. New York: Plenum Press.

Loewenstein, George (1999). Because It Is There: The Challenge of Mountaineering ... for Utility Theory. Kyklos 52(3): 315-343.

MacCulloch, Robert and Silvia Pezzini (2002). The Role of Freedom, Growth and Religion in the Taste for Revolution. Mimeo. London School of Economics. 
Marschak, Jacob (1950). Uncertain Prospects, and Measurable Utility. Econometrica 18: 111-141.

Nozick, Robert (1974). Anarchy, State, and Utopia. New York: Basic Books.

Oberholzer-Gee, Felix, Bruno S. Frey, Albert Hart and Werner W. Pommerehne (1995). Panik, Protest und Paralyse. Eine empirische Untersuchung über nukleare Endlager in der Schweiz. Schweizerische Zeitschrift für Volkswirtschaft und Statistik 13 (2): 147-177.

O'Sullivan, Arthur (1993). Voluntary Auctions for Noxious Facilities: Incentives to Participate and the Efficiency of Siting Decisions. Journal of Environmental Economics and Management 25(1): 12-26.

Oswald, Andrew J. (1997). Happiness and Economic Performance. Economic Journal 107(445): 1815-1831.

Pascal, Blaise (1670). Pensées. Paris: Port-Royal.

Peterson, Christopher (1999). Personal Control and Well-Being. In: Daniel Kahneman, Ed Diener and Norbert Schwarz (eds). Well-Being: The Foundation of Hedonic Psychology. New York: Russell Sage Foundation: 288-301.

Pommerehne, Werner W. and Hannelore Weck-Hannemann (1996). Tax Rates, Tax Administration and Income Tax Evasion in Switzerland. Public Choice 88(1-2): 161-170.

Pruitt, Stephen W. and Friedman, Monroe (1986): Determining the Effectiveness of Consumer Boycotts: A Stock Price Analysis of their Impact on Corporate Targets. Journal of Consumer Policy 9: 375-87.

Rabe, B. G. (1994). Beyond NIMBY: Hazardous Waste Siting in Canada and the United States. Washington, D.C.: Brookings Institution.

Rabin, Matthew (1993). Incorporating Fairness into Game Theory and Economics. American Economic Review 83(5): 1281-1302.

Ryff, Carol D. and Corey Lee M. Keyes (1995). The Structure of Psychological Well-Being Revisited. Journal of Personality and Social Psychology 69(4): 719-727.

Schroth, Holly A. and Priti Pradhan Shah (2000). Procedures: Do We Really Want to Know Them? An Examination of the Effects of Procedural Justice on Self-Esteem. Journal of Applied Psychology 85(3): 462-471.

Seligman, Martin E. P. (1992). Helplessness: On Depression, Development, and Death. New York: Freeman.

Sen, Amartya K. (1970). Collective Choice and Social Welfare. San Francisco: Holden-Day.

Sen, Amartya K. (1995). Rationality and Social Choice. American Economic Review 85(1): 1-24.

Sen, Amartya K. (1997). Maximization and the Act of Choice. Econometrica 65(4): 745-779.

Shiller, Robert J., Maxim Boyocko and Vladimir Korobov (1991). Popular Attitudes Toward Free Markets: The Soviet Union and the United States Compared. American Economic Review 81(3): 385-400.

Slemrod, Joel and Shlomo Yitzhaki (2002). Tax Avoidance, Evasion, and Administration. In: Alan J. Auerbach and Martin Feldstein (eds). Handbook of Public Economics, vol. 3. Amsterdam, London and New York: Elsevier.

Sugden, Robert (1981). The Political Economy of Public Choice. Oxford: Martin Robertson.

Sugden, Robert (1986). The Economics of Rights, Cooperation, and Welfare. Oxford: Blackwell.

Thaler, Richard (1991). Quasi-Rational Economics. New York: Russell Sage.

Thibaut, John and Laurens Walker (1975). Procedural Justice: A Psychological Analysis. Hillsdale, NJ: Erlbaum. 
Tyler, Tom R. (1990). Why People Obey the Law. New Haven: Yale University Press.

Tyler, Tom R. (1997). Procedural Fairness and Compliance with the Law. Swiss Journal of Economics and Statistics 133(2): 219-240.

Tyler, Tom R., Robert J. Boeckmann, Heather J. Smith and Yuen J. Huo (1997). Social Justice in a Diverse Society. Boulder, CO: Westview Press.

Tyran, Jean Robert and Dirk Engelmann (2002). To Buy or Not to Buy? An Experimental Study of Consumer Boycotts in Retail Markets. University of St.Gallen Working Paper.

Veenhoven, Ruut (1993). Happiness in Nations: Subjective Appreciation of Life in 56 Nations 1946-1992. Rotterdam: Erasmus University Press.

von Neumann, John and Oskar Morgenstern (1944). Theory of Games and Economic Behavior. Princeton: Princeton University Press.

Waterman, Alan S. (1993). Two Conceptions of Happiness: Contrasts of Personal Expressiveness (Eudaimonia) and Hedonic Enjoyment. Journal of Personality and Social Psychology 64(4): 678-691.

Weibel, Antoinette and Sandra Rota (2001). Fairness as a Motivator. In: Bruno S. Frey and Margit Osterloh (eds). Succesful Management by Motivation. Berlin and New York: Springer: 171-188.

White, R. Winthrop (1959). Motivation Reconsidered: The Concept of Competence. Psychological Review 66(5): 297-333. 